\title{
Increasing paddy yields and improving farm management: results from participatory experiments with good agricultural practices (GAP) in Tanzania
}

\author{
Kalimuthu Senthilkumar ${ }^{1}$ [ $\cdot$ Bonaventure J. Tesha ${ }^{1} \cdot$ Jerome $_{\text {Mghase }}{ }^{2} \cdot$ Jonne Rodenburg $^{3,4}$
}

Received: 3 October 2016 / Revised: 11 June 2018 / Accepted: 23 July 2018 / Published online: 31 July 2018

(c) The Author(s) 2018

\begin{abstract}
Rice is an increasingly important commodity in sub-Saharan Africa. In Tanzania, the rice yield gap is as high as $87 \%$, due to a combination of production constraints and sub-optimal crop management. Reducing this yield gap may be partly achieved through the introduction and dissemination of good agricultural practices (GAP). We conducted 18 farmer-managed onfarm trials in Tanzania, to test a set of GAP components against conventional farmers' practices (FP) for two consecutive growing seasons in 2013 and 2014. The objectives were: (1) to understand farmers' capabilities in implementing GAP; (2) to acquire better insights into the merits, relevance and suitability of individual GAP components; and (3) to provide a case study showing that exposure to good practices combined with the farmers' own experimentations can serve to improve and, trigger a positive change in the participating farmers' crop management. Compared to the farmers' own practices, average yield increases of $1 \mathrm{t}$ paddy ha $\mathrm{h}^{-1}$ in 2013 and $2.7 \mathrm{t} \mathrm{ha}^{-1}$ in 2014 were achieved when following GAP. These yield advantages were mainly obtained by a higher panicle number, improved harvest index and improved weed control. Farmers experienced difficulties with land levelling, planting or sowing in lines and using rotary weeders, but they were convinced that these technologies are important to boost their rice yields. The case of Tanzania shows that paddy yields can be substantially improved by GAP and that adoption of GAP by smallholder rice farmers can be triggered by stimulating experimentations with such practices on their own farms.
\end{abstract}

Keywords Integrated crop management $\cdot$ Farmers' practices $\cdot$ Subsistence farmers $\cdot$ Food security $\cdot$ Sub-Saharan Africa

\section{Introduction}

Rice (Oryza sativa and O. glaberrima) is an increasingly important staple food in sub-Saharan Africa (SSA). Tanzania is the fifth most important rice-producing country in SSA in terms of rice area with $0.94 \mathrm{M}$ ha, and the third in terms of annual paddy production with $1.13 \mathrm{M} \mathrm{t}$ (Diagne

Kalimuthu Senthilkumar

k.senthilkumar@cgiar.org

1 Africa Rice Center (AfricaRice), P.O. Box 33581, Dar es Salaam, Tanzania

2 Kilombero Agricultural Research and Training Institute (KATRIN), P.O. Box 405, Ifakara, Tanzania

3 Africa Rice Center (AfricaRice), 01 BP 4029, Abidjan, Côte d'Ivoire

4 Natural Resources Institute (NRI), University of Greenwich, Chatham Maritime, ME4 4TB Kent, UK et al. 2013). Rice yields in Tanzania are generally low. The estimated current average yields in Tanzania range from $1.1 \mathrm{t} \mathrm{ha}^{-1}$ under rainfed lowland conditions to $1.4 \mathrm{t} \mathrm{ha}^{-1}$ under irrigated conditions (Diagne et al. 2013), while potential yields for water-unlimited lowland rice range from 10 to $11 \mathrm{t} \mathrm{ha}^{-1}$ (GYGA 2015). With rice yield gaps in SSA ranging from 30 to $90 \%$ (van Oort et al. 2015), Tanzania is among the countries with the largest difference between the potential or water-limited yield and the actual yield. With such low yields, smallholder rice farmers in Tanzania, who grow rice both for their own subsistence and for the (local) market, are often stuck in a poverty trap. The sub-optimal rice productivity is caused by a myriad of production constraints and sub-optimal crop management (Nhamo et al. 2014). The current rice production practices of smallholder farmers in Tanzania include soil tillage using hand-held hoes and the use of low-yielding local varieties. The crop is established by scatter transplanting or broadcast sowing, after crop and weed residue removal and burning. Farmers do not, or not 
sufficiently, bund or level their fields, causing sub-optimal water management, and apply little or no fertilisers. Weeding is done by hand with a sub-optimal timing.

Based on previous experiences in West Africa (Haefele et al. 2000; Becker and Johnson 2001; Poussin et al. 2006), we aim to increase farmers' rice yields by introducing good agricultural practices (GAP), an integrated set of recommended crop, soil, water and weed management practices (Ceesay 2010; Nhamo et al. 2014). GAP for lowland rice may include, but is not limited to, practices such as animal or motorised traction for fine tillage, proper bunding and levelling, the use of improved varieties and certified seeds, sowing or transplanting in lines, application of judicious doses of composite fertilisers, and optimally timed weed control using proper herbicide dosages followed by weeding with mechanical weeders (Becker et al. 2003; Wopereis et al. 2007; Rodenburg and Johnson 2009).

Like other parts of SSA, Tanzania has large areas of wetlands with favourable climatic conditions for rice production. The use of GAP has recently been proposed as an important component in the strategy towards boosting rice yields (Nhamo et al. 2014) and, more specifically, for the sustainable and efficient use of Africa's wetland potential (Rodenburg et al. 2014). One such wetland for which the full potential has not yet been exploited is the Kilombero Valley in Tanzania.

The objectives of our study were: (1) to compare a set of GAP to conventional farmers' practices (FP) to quantify the possible yield advantages with GAP; (2) to understand farmers' capabilities in implementing GAP on their farms and to obtain their opinions on GAP component technologies compared to conventional practices; and (3) to provide a case study showing that on-farm farmer participatory experiments with such practices can serve to improve and prioritise rice-farming extension efforts and, trigger a positive change in the participating farmers' crop management. For this purpose, a set of farmer-managed and researcher-supported onfarm trials were conducted in representative irrigated and rainfed lowland fields for two consecutive years. Farm surveys were conducted to evaluate farmers' perceptions and experiences with the improved practices and to investigate the likelihood that proposed interventions could change current farmer practices in the long run. This specific case of the Kilombero Valley is discussed within the broader context of rice sector development in sub-Saharan Africa.

\section{Materials and methods}

\section{On-farm trial set-up}

A total of 18 on-farm trials were conducted during the main rice cropping season (February-June) in 2013 and 2014 in six villages in the Kilombero Valley, Tanzania (the villages of Mkula and Msufini, Mkula ward; the villages of Kisawasawa and Ichonde, Kisawasawa ward; and the villages of Idete and Namwawala, Idete ward), roughly between $8^{\circ} 11^{\prime} \mathrm{S}-36^{\circ} 15^{\prime} \mathrm{E}$ and $7^{\circ} 52^{\prime} \mathrm{S}-36^{\circ} 53^{\prime} \mathrm{E}$ (Fig. 1). The Kilombero Valley has an area of $7969 \mathrm{~km}^{2}$ and a catchment area of about $40,000 \mathrm{~km}^{2}$ (Felister et al. 2011) and generates more than $30 \%$ of Tanzania's annual domestic rice production (Kilimo Trust 2014).

The trials, comparing two rice production methods (GAP and FP), were conducted by three representative volunteer farmers per village ( 3 farmers $\times 6$ villages $=18$ trials). Participating farmers were selected by the local agricultural district officer and the respective village chief. The specific aim was to conduct trials that were (1) representative in terms of production environment, farm size, resource endowment and yield levels, (2) representative and balanced in terms of gender, and (3) that involved volunteer farmers with a keen interest in participating in the study. Quantitative data (i.e. yield and yield attributes) concerning the performance of each method were collected from each of the farms, while farmers were interviewed to substantiate their agronomic perceptions concerning the performance and feasibility of the GAP methods and components. A two-day participatory training workshop for the farmers was organised before the start of each season to introduce the farmers to a set of GAP and to train them on the implementation of the practices. Among these 18 farmers, eight had access to irrigation water and already used transplanting. We refer to them below as the 'irrigated-rice farmers'. The remaining ten farmers were dependent on rainfall and used direct sowing. We refer to them below as the 'rainfed-rice farmers'. The gender ratio (M:F) among this group of participating farmers was 1:1, reflecting the gender ratio of the rice farmers in this area. Each farmer was asked to select two adjacent plots in his/her field, one for testing good agricultural practices (GAP) and the other for implementing their usual practices (FP). Farmers' individual plot sizes per practice (GAP or FP) ranged between 358 and $2173 \mathrm{~m}^{2}$ in 2013, and between 741 and $2173 \mathrm{~m}^{2}$ in 2014, respectively; the two plots of an individual farmer were approximately equal in size in both years. Once every 2 weeks and at the time of the actual implementation of an important intervention, researchers and enumerators monitored the farmers' implementation of GAP. For the first season, each farmer was provided with a total budget of US $\$ 100$ to cover any additional input costs for GAP; in the second season, after consulting with farmers and extension services, this amount was raised to US $\$ 150$. The idea behind this was to leave farmers with a free choice of GAP components to be implemented and to allow them to assess the different components not only on their merits for crop yields but also on their monetary costs. Farmers received logistic assistance for the acquisition of certified seeds and 


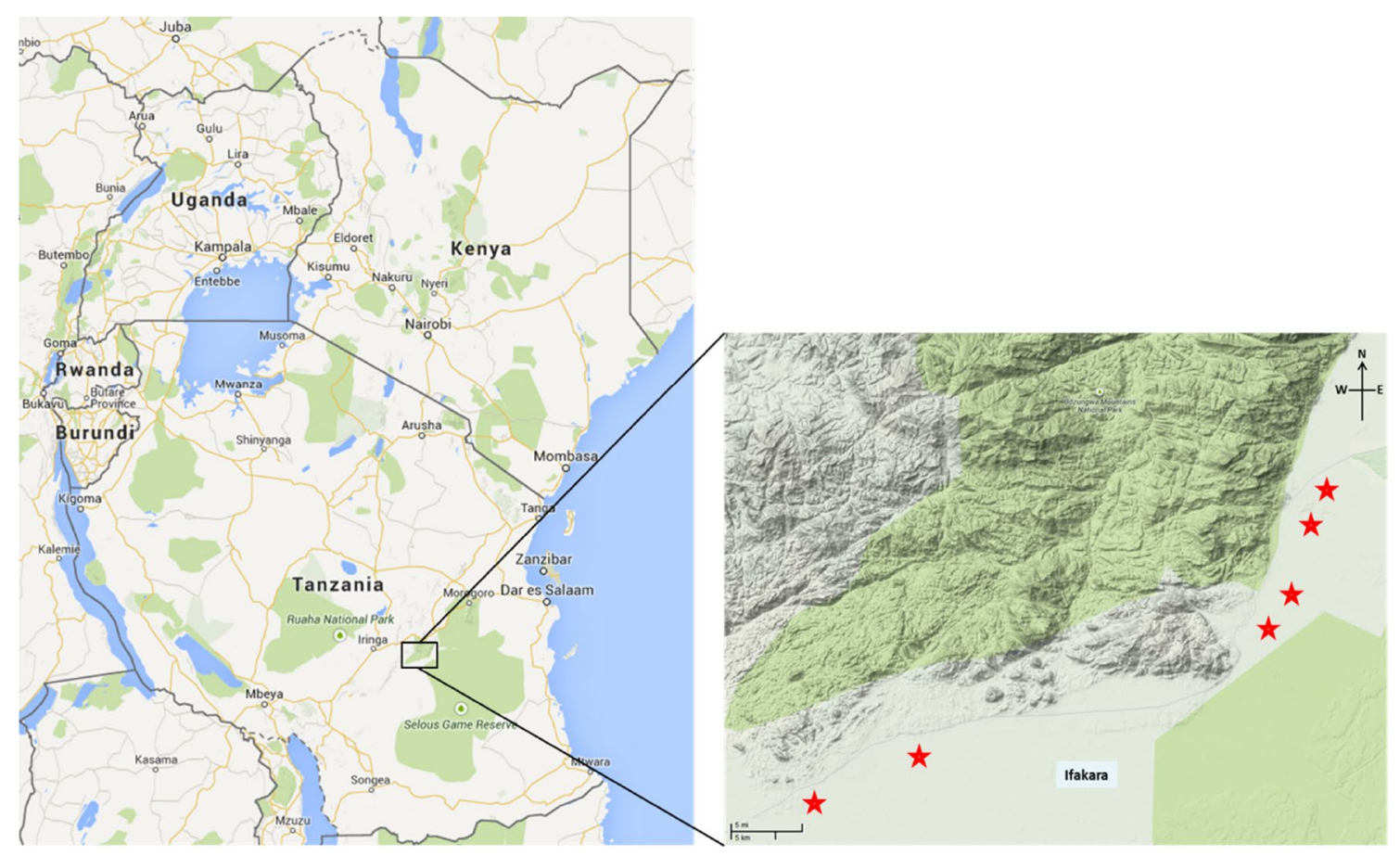

Fig. 1 Map showing the location of the 18 on-farm trials in the Kilombero Valley, Tanzania. Each star represents a village and three on-farm trials were conducted in each village, both in 2013 and 2014

inorganic fertilisers since they were not readily available on the local markets. Plant-protection measures against pests and diseases were left to the farmers' discretion.

The list of GAP component technologies introduced to the farmers along with their conventional rice cultivation practices (FP) is presented in Table 1. The GAP component technologies were proposed to farmers based on existing proven technologies (Becker and Johnson 2001; Nwite et al. 2008). Land clearing was included as a GAP to avoid shrubs and tree trunks in the field so as to facilitate tillage and subsequent operations. Tillage with animals or motorised traction, bunding, levelling and puddling, line planting or line sowing, thinning and gap filling are technologies that have been proven to increase rice yields. These practices provide a homogeneous crop with an optimal use of the available space and favourable conditions for crop and weed management operations (Becker et al. 2003; Wopereis et al. 2007; Rodenburg and Johnson 2009).

For the fertiliser application rate proposed under GAP, the recommendations of the regional Rice Research Centre of Excellence, the Kilombero Agricultural Research and Training Institute (KATRIN), were followed: $\mathrm{N}: \mathrm{P}_{2} \mathrm{O}_{5}$ at $80: 40 \mathrm{~kg} \mathrm{ha}^{-1}$. All P fertiliser was applied as basal, whereas $\mathrm{N}$ was split into three different applications, i.e. $16 \mathrm{~kg} \mathrm{~N} \mathrm{ha}^{-1}$ as basal, $32 \mathrm{~kg} \mathrm{~N} \mathrm{ha}^{-1}$ at 20 days after transplanting (DAT; for irrigated rice) or days after sowing (DAS; for rainfed rice), and $32 \mathrm{~kg} \mathrm{~N} \mathrm{ha}^{-1}$ at 40 DAT/DAS. This rate and timing was based on the prevailing soil fertility status and previous crop responses to applied nutrients (Mowo et al. 1993). Nitrogen and phosphorus fertilisers were applied in the form of urea and di-ammonium phosphate (DAP), respectively. Application of potassium fertiliser was not recommended following unavailability on the local market.

Weed management practices under GAP consisted of the use of the well-timed pre-emergence herbicide application of oxadiazon $\left(0.5-0.75 \mathrm{~kg}\right.$ a.i. $\mathrm{ha}^{-1}$ at 4-5 DAT), combined with weeding interventions using mechanical weeders at 21 and 42 DAT/DAS. The common practice used by farmers in Kilombero involves hand-weeding two times during the season and, occasionally, the application of post-emergence herbicides. Hand-weeding is very labour intensive (LodinBergman et al. 2012; Ogwuike et al. 2014). Due to labour shortages, hand-weeding is often incomplete or untimely, resulting in large yield losses (Rodenburg and Johnson 2009; Rodenburg et al. 2011; Nhamo et al. 2014). Moreover, very few farmers use herbicides in a timely and correct manner (Rodenburg and Johnson 2009), resulting in sub-optimal weed control or crop damage and concomitant yield reductions. The mechanical weeder proposed under GAP offers an effective and labour-saving alternative to hand-weeding and post-emergence herbicides (Krupnik et al. 2012; Rodenburg et al. 2015). Three types of mechanical weeders (cono weeder, straight spike floating weeder and twisted spike floating weeder) were supplied to all the farmers to be used in the GAP plots. 


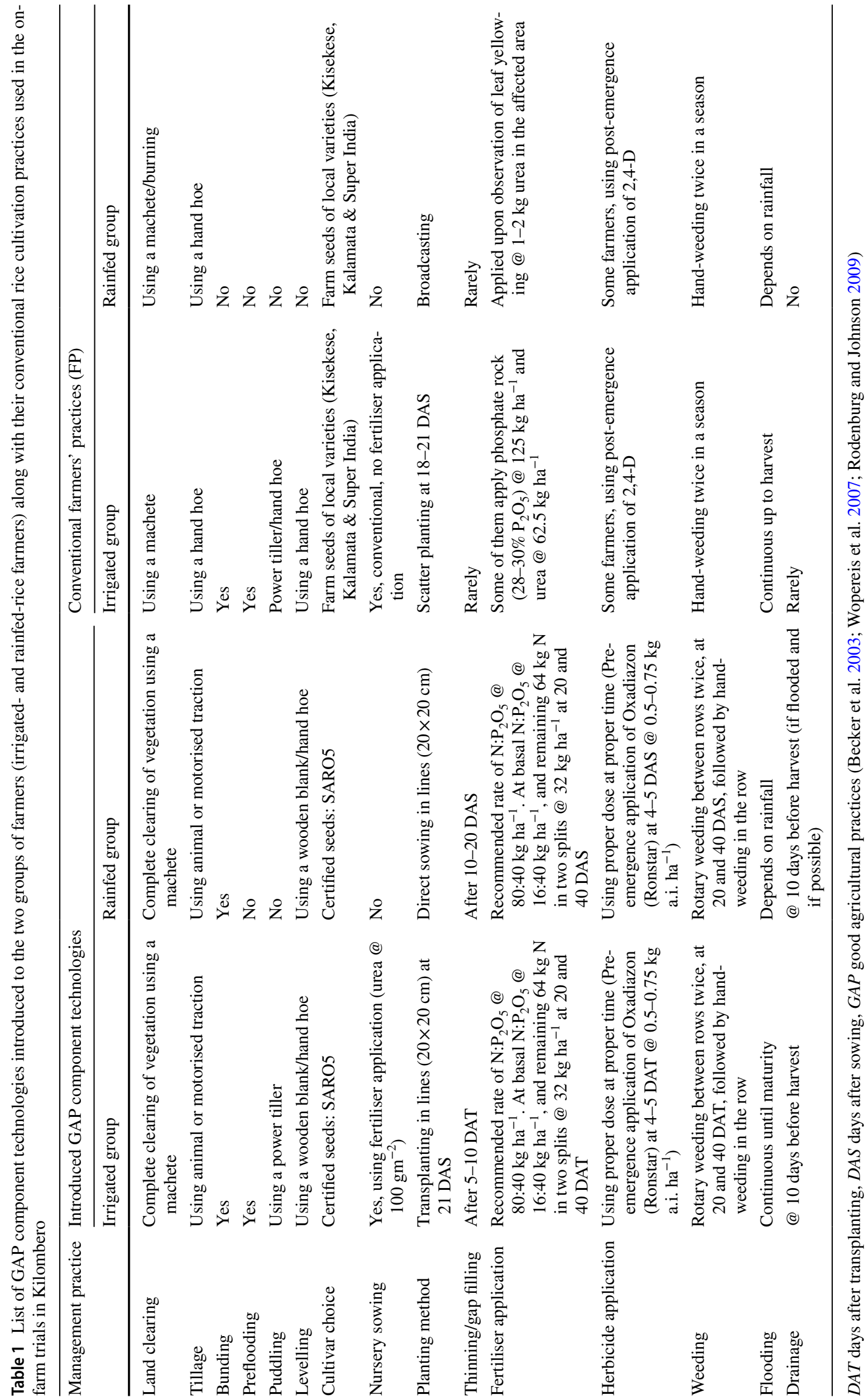


The certified seeds of the popular improved variety, SARO5, were used in all the GAP plots, whereas in the FP plots, farmers used local varieties such as Kisekese, Kalamata and Super India. SARO5 is an improved, medium duration (120 days), semi-aromatic, high-yielding variety that is gaining popularity among Kilombero farmers (Nhamo et al. 2014).

Soil samples were taken from both GAP $(n=18)$ and FP ( $n=18$ ) plots before (at sowing/transplanting) and after each rice-growing season, with the soil samplings after season 1 and before season 2 combined $(n=3)$. Soils were analysed for texture, macro- and micronutrients and their suitability for rice cultivation. This resulted in a total of 108 soil samples. The soil analysis was done by the Crop Nutrition Laboratory Services (CROPNUTS), ISO 17025 accredited, Nairobi, Kenya. The analytical methods used to analyse the soil samples are presented in Table 2.

\section{Measurement of yield and yield attributes}

Within each GAP and FP plot, two harvest areas of $4 \mathrm{~m}^{2}$ $(2 \times 2 \mathrm{~m})$ were marked for yield assessments by the researchers. Rice panicles from these two $4-\mathrm{m}^{2}$ harvest areas were harvested and threshed and grains were winnowed to remove empty spikelets. The retrieved rice grain weights were assessed with a digital weighing scale, and grain moisture contents were assessed at the same time using a digital grain moisture meter (SATAKE Moistex Model SS-7) to correct for differences in moisture content. Rice grain yields from the two harvest areas were then averaged and expressed in $\mathrm{tha}^{-1}$ at $14 \%$ moisture content. Within each harvest area, a $1-\mathrm{m}^{2}$ area $(1 \times 1 \mathrm{~m})$ was earmarked for detailed observations on the following yield-attributing characteristics: number of hills, tiller number, panicle number, plant height, 1000-grain weight, percentage of filled grains and harvest index. The final values were reached by averaging the data from the two $1-\mathrm{m}^{2}$ areas per plot. The percentage of filled grains and harvest index were assessed in 2014 only by harvesting all the hills from the two $1-\mathrm{m}^{2}$ harvest areas. In order to evaluate the weed pressure after implementing the weeding operations in both GAP and FP plots, weed biomass $\left(\mathrm{g} \mathrm{m}^{-2}\right)$ was assessed by collecting all the weeds from the same two $1-\mathrm{m}^{2}$ areas just before harvest and oven-drying the samples at $70{ }^{\circ} \mathrm{C}$ for $48 \mathrm{~h}$. In addition to the yield assessment from the two $4-\mathrm{m}^{2}$ harvest areas conducted by the researchers, the farmers' harvested yields from the entire GAP and FP plots were estimated during the farmer surveys ('Farm surveys' section). Farmers were asked to express the harvested yield in number of bags, which was then converted to $t \mathrm{ha}^{-1}$ using mean weight of a rice bag $\left(150 \mathrm{~kg} \mathrm{bag}^{-1}\right)$ for the study site. Furthermore, the neighbouring farmers were asked to anticipate the yields from the GAP and FP plots based on visual appearances during the farmer field days ('Farmer field days' section) and presented in $\mathrm{tha}^{-1}$. The yield, yield attributes and dry weed biomass data for the GAP and FP practices were subjected to analysis of variance (ANOVA) using XLSTAT (Addinsoft 2007) followed by a comparison of means with Fisher's protected LSD test at 5\% to analyse differences between the two principal set of practices. Pearson correlation analysis was performed to show the relationship between yield and panicle number. A multiple regression analysis was performed to identify the impact of individual GAP component technologies on researcher-measured yield in GAP plots based on their use or non-use by the participating farmers. This analysis was conducted for irrigated $(n=17)$ and rainfed $(n=19)$ farmers separately but combining the data for both 2013 and 2014 seasons. The GAP component technologies used by all the farmers (e.g. land clearing, tillage, use of improved varieties) were excluded from the analysis as their impact on yield were the same in principle. Only the GAP component technologies that were used by some farmers while not used by others were included in the analysis. For each GAP, a qualitative value of ' 1 '

Table 2 Analytical methods used to analyse the soil samples

\begin{tabular}{ll}
\hline Parameter & Analytical method* \\
\hline Soil pH & Potentiometric (soil:water 1:2) \\
Soil EC & Potentiometric (soil:water 1:2) \\
Soil Ca, Mg, K, Na, Mn, Fe, Cu, Mo, B, Zn, S & $\begin{array}{c}\text { Atomic emission spectrometry (ICP) (Mehlich 3—Diluted ammonium fluoride and ammonium } \\
\text { nitrate) } \\
\text { Soil available Phosphorus (P Olsen) }\end{array}$ \\
Colorimetric (Sodium bicarbonate Extractant. Complex formation of ammonium molybdate) \\
Soil Carbon & Colorimetric (UV-Vis)—Kjeldahl digestion \\
& Walkley and Black method (Colorimetric)—Wet oxidation by acidified dichromate in the pres- \\
Soil texture (\% Clay, Silt, Sand) & ence of sulphuric acid \\
\hline
\end{tabular}

*For detailed description of analytical methods, refer to Pansu and Gautheyrou (2007) and van Ranst et al. (1999) 
is given if used and ' 2 ' if not used and the analysis was performed using XLSTAT.

\section{Farm surveys}

In both seasons, two farmer surveys were conducted during the course of the trials using predesigned questionnaires. The aim of the first farmer survey was to record which of the GAP component technologies the farmers actually implemented, and how. Farmers' own practices concerning the use of locally available organic manures were also recorded during this survey. The second farmer survey was conducted at the end of the trials and focused on farmers' opinions about GAP component technologies such as their preference ('like', 'not like' and 'partly like'), importance ('important', 'not important' and 'not sure'), workability ('easy', 'difficult' and 'no difference') and possible use by the farmers in the future ('yes', 'no' and 'not sure').

\section{Farmer field days}

In both years, just before rice harvest, six farmer field days were conducted by inviting an additional 15 farmers per field day from each village (a total of 90 farmers per year) to visit the trial plots of that specific village. The main objectives of the farmer field days were to create awareness of GAP among the neighbouring farmers in the village and to obtain their opinions, as well as those of the farmers who implemented the trials. The visiting farmers were given an introduction to the on-farm trials and the technologies being introduced into the GAP plots. They were asked to predict the yields from the GAP and FP plots based on visual appearances. Farmers were also asked about the GAP component technologies that they learned during the farmer field days and their intention and willingness to implement them and to take part in similar on-farm trials in the future, as a concrete token of their interest in GAP and in improving their own crop management practices.

\section{Results and discussion}

\section{Soil fertility status}

The soil fertility status of the trial plots (both GAP and FP) was generally poor (Table 3 ). The mean soil texture composition was $70 \%$ sand, $20 \%$ clay and $10 \%$ silt. When compared with the critical levels below which nutrient deficiency for individual nutrients occur for rice production (Fairhurst et al. 2007), we found that the N, P, K, Mg, S and B are below the

Table 3 Soil nutrient status of the farmers' fields where the on-farm trials were conducted. A total of 108 samples were analysed during the 2-year period of the on-farm trials ( 2 treatments $\times 18$ fields $\times 3$ times sampling)

\begin{tabular}{|c|c|c|c|c|c|c|c|}
\hline Parameter & Unit & $n$ & Minimum & Maximum & Average & $\begin{array}{l}\% \text { samples below the critical } \\
\text { soil nutrient levels for rice }\end{array}$ & $\begin{array}{l}\text { Critical soil } \\
\text { nutrient levels } \\
\text { for rice }\end{array}$ \\
\hline $\mathrm{pH}$ & - & 108 & 5.21 & 6.95 & 5.90 & - & - \\
\hline $\mathrm{EC}$ & $\mu \mathrm{S} / \mathrm{cm}$ & 108 & 14.00 & 125.00 & 44.39 & - & - \\
\hline C.E.C & $\mathrm{meq} / 100 \mathrm{~g}$ & 108 & 3.76 & 30.50 & 13.11 & - & - \\
\hline $\mathrm{C}$ & $\%$ & 108 & 1.28 & 3.22 & 2.05 & - & - \\
\hline $\mathrm{N}$ & $\%$ & 108 & 0.12 & 0.21 & 0.16 & 60 & $<0.2$ \\
\hline $\mathrm{P}($ Olsen $)$ & ppm & 108 & 2.33 & 40.60 & 10.43 & 14 & $<5$ \\
\hline K & ppm & 108 & 18.30 & 277.00 & 83.73 & 27 & $<58.5$ \\
\hline $\mathrm{Ca}$ & ppm & 108 & 376.00 & 3490.00 & 1209.39 & 0 & $<200$ \\
\hline $\mathrm{Mg}$ & ppm & 108 & 69.20 & 793.00 & 373.01 & 6 & $<120$ \\
\hline $\mathrm{Mn}$ & ppm & 108 & 30.50 & 196.00 & 75.37 & 0 & $<12-20$ \\
\hline $\mathrm{S}$ & ppm & 108 & 2.48 & 20.10 & 8.42 & 41 & $<5-9$ \\
\hline $\mathrm{Cu}$ & ppm & 108 & 0.33 & 7.17 & 2.33 & 0 & $<0.1-0.3$ \\
\hline B & ppm & 108 & 0.04 & 0.26 & 0.13 & 100 & $<0.5$ \\
\hline $\mathrm{Zn}$ & ppm & 108 & 1.00 & 5.94 & 3.27 & 0 & $<0.6$ \\
\hline $\mathrm{Na}$ & ppm & 108 & 23.30 & 159.00 & 80.64 & - & - \\
\hline $\mathrm{Fe}^{* *}$ & ppm & 108 & 142.00 & 724.00 & 388.53 & 0 & $<2-5$ \\
\hline Silt & $\%$ & $72 *$ & 3.48 & 20.50 & 9.56 & - & - \\
\hline Sand & $\%$ & $72 *$ & 52.50 & 87.40 & 69.80 & - & - \\
\hline Clay & $\%$ & $72 *$ & 6.00 & 34.10 & 20.54 & - & - \\
\hline
\end{tabular}

*The first set of soil samples $(n=36)$ were not analysed for soil texture

** $51 \%$ of the samples had $>300 \mathrm{ppm}$ of Fe, which is the critical soil level for occurrence of Fe toxicity 
critical levels in most rice fields in the Kilombero Valley. In the case of nitrogen $(\mathrm{N}), 60 \%$ of the samples were below the critical level of $0.2 \%$ (Laker 2005). Nitrogen is among the most important nutrients for rice production; application of appropriate doses of nitrogen alone can already boost lowland rice yields by close to $1 \mathrm{t} \mathrm{ha}^{-1}$ (Tanaka et al. 2013). Phosphorus (P) and potassium (K) were below the critical levels in 14 and $27 \%$ of the soil samples, respectively (Table 3). Magnesium (Mg) and sulphur (S) were below the critical levels in 6 and $41 \%$ of the samples, respectively. Boron (B) was found to be below critical levels in all the samples. While iron $(\mathrm{Fe})$ content was above the critical levels for the occurrence of mineral toxicity (>300 ppm) in $51 \%$ of the samples, iron toxicity symptoms were not observed in our trials in either of the seasons. Given the existing genetic variation in iron toxicity tolerance across lowland rice varieties (Becker and Asch 2005; Olaleye et al. 2009), this could possibly be explained by a certain degree of tolerance in the rice varieties used here, reducing or masking symptoms of iron toxicity. Similarly, high concentrations of $\mathrm{Ca}$ were found in Kilombero soils, with an average $\mathrm{Ca}$ content of 1200 ppm (Table 3).
Conventionally, rice farmers in Kilombero did not apply any fertilisers, neither organic nor inorganic (Table 1). This practice, coupled with repeated removal of nutrients through the crop could be the cause for the poor soil fertility status of these soils. This poor soil fertility may be an important limiting factor for rice yields. Haefele et al. (2002a) showed that irrigated-rice yields without any fertiliser inputs are about half that of the yields obtained with optimal fertiliser application. Without optimal levels of required macro- and micronutrients, implementation of improved crop management practices, other than applying more nutrients, may also not yield the desired benefits (Tittonell and Giller 2013). High soil $\mathrm{Fe}$ and $\mathrm{Ca}$ contents may lead to fixation of $\mathrm{P}$, as previously shown by Fageria et al. (2011) and Haefele et al. (2014), and this may lead to a lower use efficiency of applied $P$ fertilisers. Whether this is the case for the soils in the Kilombero Valley would be subject to further investigation. Application of micronutrients through foliar spraying could be an option to overcome nutrient fixation by $\mathrm{Ca}$ - and $\mathrm{Fe}$ rich soils (Rashid and Ryan 2004; Jin et al. 2008; Boonchuay et al. 2013).

Table 4 Percentage of farmers using the introduced GAP component technologies in Kilombero in 2013 and 2014

\begin{tabular}{|c|c|c|c|c|}
\hline \multirow[t]{3}{*}{ GAP component technologies } & \multicolumn{4}{|c|}{ Farmers $(\%)$ used GAP } \\
\hline & \multicolumn{2}{|l|}{2013} & \multicolumn{2}{|l|}{2014} \\
\hline & Irrigated group & Rainfed group & Irrigated group & Rainfed group \\
\hline Land clearing & 100 & 100 & 100 & 100 \\
\hline Tillage & 100 & 100 & 100 & 100 \\
\hline Bunding & 100 & 100 & 100 & 78 \\
\hline Preflooding & 100 & 10 & 100 & 0 \\
\hline Puddling & 100 & 20 & 100 & 11 \\
\hline Levelling & 100 & 100 & 100 & 67 \\
\hline Use of certified seeds & 100 & 100 & 100 & 100 \\
\hline Nursery sowing & 100 & 100 & 100 & 11 \\
\hline Direct sowing in $20 \times 20 \mathrm{~cm}$ spacing & 0 & 100 & 0 & 89 \\
\hline Transplanting in $20 \times 20 \mathrm{~cm}$ spacing & 100 & 0 & 100 & 11 \\
\hline Thinning/gap filling & 100 & 100 & 100 & 100 \\
\hline Inorganic fertiliser (basal application) & 13 & 0 & 100 & 100 \\
\hline Inorganic fertiliser (first top dressing) & 100 & 100 & 100 & 100 \\
\hline Inorganic fertiliser (second top dressing) & 100 & 90 & 100 & 100 \\
\hline Organic fertiliser application & 0 & 0 & 0 & 0 \\
\hline Herbicide application & 13 & 20 & 11 & 22 \\
\hline Rotary weeding (first weeding) & 75 & 20 & 100 & 0 \\
\hline Rotary weeding (second weeding) & 63 & 0 & 100 & 0 \\
\hline Hand-weeding (first hand-weeding) & 88 & 80 & 89 & 100 \\
\hline Hand-weeding (second hand-weeding) & 88 & 80 & 89 & 100 \\
\hline Flooding & 100 & 80 & 100 & 0 \\
\hline Drainage & 88 & 0 & 100 & 0 \\
\hline
\end{tabular}




\section{Implementation of GAP component technologies}

Most of the introduced GAP component technologies were implemented by all 18 farmers (Table 4) in both years. Moreover, the farmers showed improvements in implementing GAP in 2014 compared to 2013. For instance, 75 and 63\% of irrigated-rice farmers used mechanical weeders for the first and second weeding, respectively, in 2013, compared to $100 \%$ in 2014 . The reasons for not using the mechanical weeders in the first year were: (1) lack of sufficient water to facilitate the operation; (2) difficulties with operating the weeders in the field; and (3) fear of damaging the rice crop. However, the farmers overcame these challenges in 2014. Similar difficulties with operating the mechanical weeders were reported in southern India (Senthilkumar et al. 2008). In the case of the rainfed-rice farmers, only a few (20\%) used mechanical weeders for the first weeding in 2013 and none used mechanical weeders afterwards. The three types of mechanical weeders (cono weeder, straight spike floating weeder and twisted spike floating weeder) introduced to these farmers are mechanical weeders with a floater in front. These weeders require a layer of water $(2-5 \mathrm{~cm}$ in depth) for proper operation (Senthilkumar et al. 2008). Without this water layer, the soil could stick to the weeder spikes making it difficult to operate (Rodenburg et al. 2015). This may have caused the non-adoption of these rotary weeders by the rainfed-rice farmers. This experience underpins the need for mechanical weeders specific to rice-growing conditions to be designed, introduced and tested using a participatory approach of farmers, similar to what has been done by Gongotchame et al. (2014) in Benin.

Bunding and levelling were carried out by all the farmers in 2013; however, only 78 and $67 \%$ of the rainfed-rice farmers repeated these operations in 2014. The main reason for this drop in the number of farmers is that most of them used the same field as in the previous year and, consequently, there was no need or a reduced need to level and bund again. Bunding and levelling are essential components for lowland rice production and may boost rice yields by as much as 40\% (Becker and Johnson 2001; Touré et al. 2009) due to improved water, soil fertility and weed management following these practices.

GAP component technologies such as preflooding and puddling were not used by the rainfed-rice farmers due to limited water availability, although some of them could implement these technologies when they collect rainwater in their fields using bunds (Table 4). Of the irrigated-rice farmers, 13 and $11 \%$ followed up on the herbicide use recommendations in GAP plots to control weeds, whereas this figure was 20 and 22\% in 2013 and 2014, respectively, for the rainfed-rice farmers (Table 4). In general, herbicide use by rice farmers in SSA is low, probably due to a lack of information and expertise among farmers and imperfect agro-chemical supply markets (Rodenburg and Johnson 2009). In the first season, $20 \%$ of the rainfed-rice farmers could not flood their GAP plots due to lack of rainwater, and $12 \%$ of the irrigated-rice farmers could not drain their GAP plot before harvesting due to lack of drainage channels (Table 4). In 2014, all the irrigated-rice farmers were able to flood and drain the water when it was necessary, while the rainfed-rice farmers still had no control over water. Water management is an inherent common constraint to rice production in rainfed lowlands (Nguyen and Ferrero 2006; Balasubramanian et al. 2007). The lack of water control also limits the proper use of herbicide application (Zimdahl 2007), as well as the implementation of mechanical weeders (Senthilkumar et al. 2008; Rodenburg et al. 2015).

In general, during the first season, it was observed that farmers could not execute all the GAP technologies on time due to a lack of knowledge and capacity for timely execution; the researchers needed to follow up on this with them regularly. After a second training session on GAP technologies in 2014, the farmers implemented the GAP technologies more timely and precisely than during the first season.

\section{Yield advantages with GAP component technologies}

The comparative yield advantages were studied using three different methods of yield assessment: (1) visual assessment by visiting farmers; (2) researcher measurements; and (3) estimations of total harvest by participating farmers.

\section{Visiting farmers' anticipated rice yields}

During the farmer field days, visiting farmers visually assessed the crop appearance and anticipated the yield from both GAP and FP plots. More than $90 \%$ of the visiting farmers anticipated higher yields in GAP plots than in FP plots in 2013, while all the farmers anticipated higher yields in GAP plots compared to FP plots in 2014 (Fig. 2a). The mean anticipated yields for FP and GAP plots were 3.6 and $6.4 \mathrm{t} \mathrm{ha}^{-1}$ in 2013, and 4.0 and $7.1 \mathrm{t} \mathrm{ha}^{-1}$ in 2014, respectively (Table 5). In 2013, 4\% of the farmers anticipated equal yields and $4 \%$ anticipated lower yields from GAP plots compared to FP plots, while no farmers anticipated lower yields from GAP plots compared to FP plots in 2014. In both years, all visiting farmers had a positive opinion of GAP component technologies and showed a willingness to participate in similar on-farm trials in the future and to experiment with the components in their own fields. The farmer field days were organised as a means to create awareness through demonstration (Heiniger et al. 2002; Kondylis et al. 2014) of the GAP component technologies. The positive feedback of the visiting farmers on GAP technologies could have a positive impact on the adoption of such technologies in their 
(a) Visiting farmers' anticipated yield
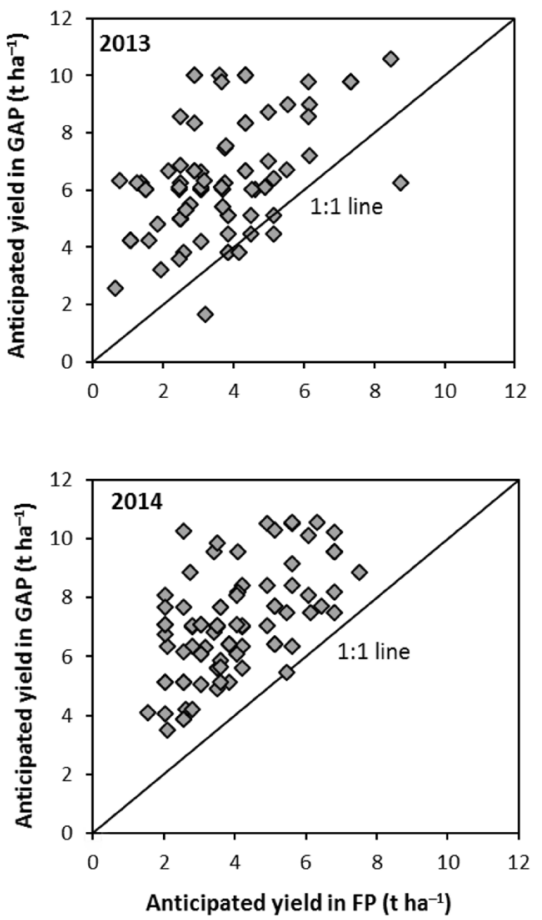

(b) Researcher-measured yield
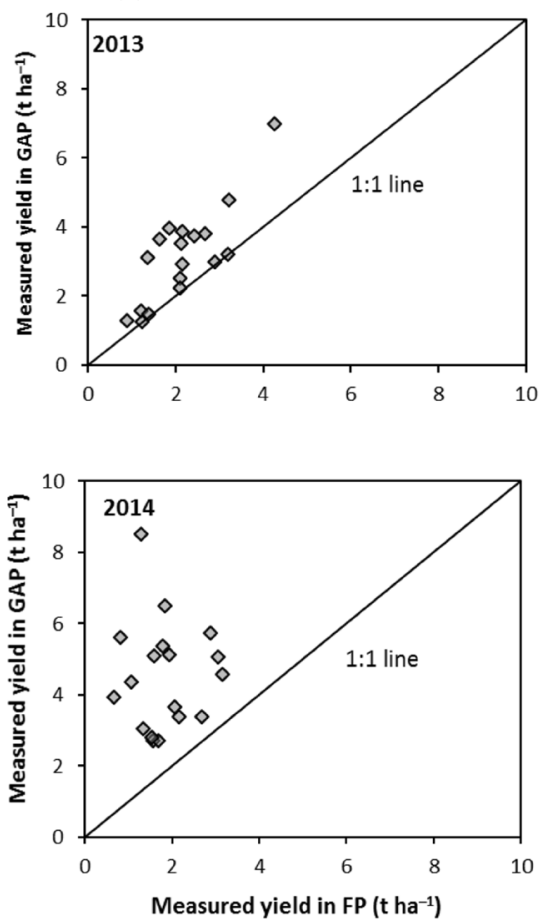

(c) Farmer-harvested yield
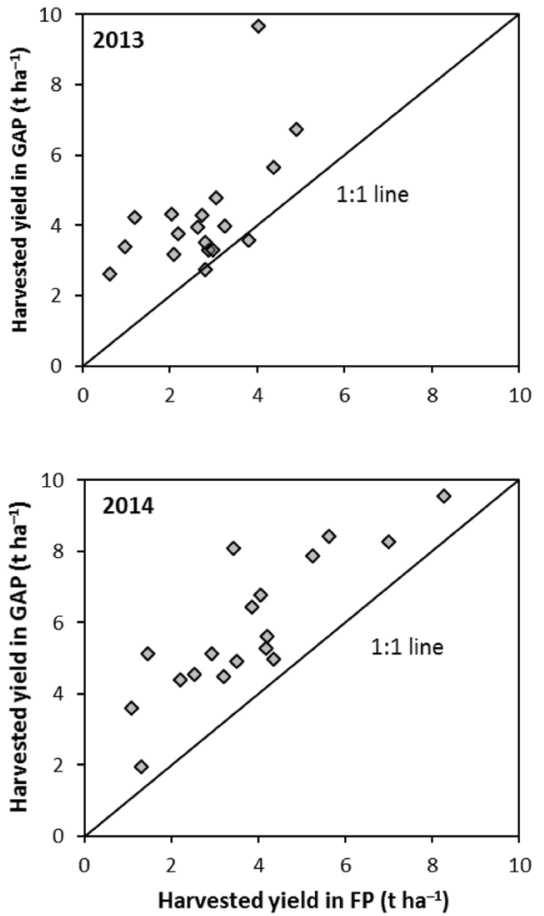

Fig. 2 Yield advantage of GAP (good agricultural practices) over FP (farmers' practices) in the on-farm trials as anticipated by the visiting farmers during the farmer field days $(n=90)$, as measured by the

own field. Since all the farmers come from a rather densely populated rice-growing area, farmer-to-farmer transfer of obtained experiences and knowledge could lead, in turn, to the increasing adoption of GAP components in the wider Kilombero Valley.

\section{Researcher-measured rice yields}

The researcher-measured yields in GAP plots were always higher than $88 \%$ or on par (12\%) with the measured yields from FP plots in 2013, while all of the GAP plots registered higher yields in 2014 (Fig. 2b). Yields from GAP plots ranged from 1.3 to $7.0 \mathrm{tha}^{-1}$ with a mean yield of $3.2 \mathrm{tha}^{-1}$ in 2013 , and from 2.7 to $8.5 \mathrm{t} \mathrm{ha}^{-1}$ with a mean yield of $4.5 \mathrm{t} \mathrm{ha}^{-1}$ in 2014, whereas in FP plots, yields ranged from 0.9 to $4.3 \mathrm{t} \mathrm{ha}^{-1}$ with a mean yield of $2.2 \mathrm{t} \mathrm{ha}^{-1}$ in 2013, and 0.7-3.2 $\mathrm{tha}^{-1}$ with a mean yield of $1.8 \mathrm{t} \mathrm{ha}^{-1}$ in 2014 (Table 5 and Fig. 2b). Overall, increased yields were obtained in GAP plots in 2014 compared to 2013, which was due to a better understanding and better implementation of GAP component technologies (Table 4). Farmers learned to work with the GAP component technologies in the course of time by familiarising themselves with the techniques, as advocated by Foster and Rosenzweig (1995) and Luh (1995). Similar experiences were observed with researchers $(n=18)$, and as harvested by the farmers $(n=18)$ in the Kilombero Valley in 2013 and 2014

introduced technologies in rice-growing countries such as Senegal (Krupnik et al. 2012) and India (Senthilkumar et al. 2011, 2012).

\section{Farmers' estimations of rice yields}

Similar trends of yield advantages in GAP plots were obtained with the farmer-estimated rice yields. Farmer-estimated rice yields in GAP plots ranged from 2.6 to $9.7 \mathrm{t} \mathrm{ha}^{-1}$ in 2013 and from 2 to $9.5 \mathrm{t} \mathrm{ha}^{-1}$ in 2014. Farmer-estimated yields in FP plots ranged from 0.6 to $4.9 \mathrm{t} \mathrm{ha}^{-1}$ in 2013 and from 1.1 to $8.3 \mathrm{t} \mathrm{ha}^{-1}$ in 2014 (Fig. 2c). The mean farmerestimated rice yields were 4.3 and $5.9 \mathrm{t} \mathrm{ha}^{-1}$ in GAP plots and 2.7 and $3.8 \mathrm{tha}^{-1}$ in FP plots for 2013 and 2014, respectively (Table 5). The wide range of yield estimates by farmers could be attributed to the general managerial capacity of the farmers, to the knowledge and capacity of individual farmers to implement the GAP component technologies properly and in a timely manner in the field, and to the inherent differences in soil physical and chemical properties as well. The soil nutrient analysis suggested that the yield could be limited by any of the macro- or micronutrients since the levels of these nutrients were below the critical level in many of the farmers' fields (Table 3). Importantly, similar to the yields from the GAP plots, the mean yields from the FP plots also increased by $1 \mathrm{t} \mathrm{ha}^{-1}$ in 2014 compared to 
Table 5 ANOVA for yield, yield attributes and weed biomass comparing farmers' practice (FP) and good agricultural practices (GAP) in the year 2013 and 2014

\begin{tabular}{|c|c|c|c|c|c|c|c|}
\hline Parameter & Unit & Year & $n$ & $\begin{array}{l}\text { Farmers' practice } \\
\text { (FP)_LS mean }\end{array}$ & $\begin{array}{l}\text { Good agricultural practice } \\
\text { (GAP)-LS mean }\end{array}$ & SE & $P$ value \\
\hline \multirow[t]{2}{*}{ Yield-researchers measured } & \multirow[t]{2}{*}{$\mathrm{tha}^{-1}$} & 2013 & 18 & 2.2 & 3.2 & 0.27 & 0.013 \\
\hline & & 2014 & 18 & 1.8 & 4.5 & 0.28 & $<0.0001$ \\
\hline \multirow[t]{2}{*}{ Yield_farmers' estimated } & \multirow[t]{2}{*}{$\mathrm{tha}^{-1}$} & 2013 & 18 & 2.7 & 4.3 & 0.48 & 0.003 \\
\hline & & 2014 & 18 & 3.8 & 5.9 & 0.64 & 0.003 \\
\hline \multirow[t]{2}{*}{ Yield-visiting farmers' anticipated } & \multirow[t]{2}{*}{$\mathrm{tha}^{-1}$} & 2013 & 90 & 3.6 & 6.4 & 0.19 & $<0.0001$ \\
\hline & & 2014 & 90 & 4.0 & 7.1 & 0.17 & $<0.0001$ \\
\hline \multirow[t]{2}{*}{ Plant population (number of hills) } & \multirow[t]{2}{*}{$\mathrm{m}^{-2}$} & 2013 & 18 & 22.6 & 23.1 & 0.85 & 0.662 \\
\hline & & 2014 & 18 & 22.5 & 23.0 & 0.88 & 0.673 \\
\hline \multirow[t]{2}{*}{ Tiller number at harvest } & \multirow[t]{2}{*}{$\mathrm{m}^{-2}$} & 2013 & 18 & 184.7 & 261.7 & 19.48 & 0.008 \\
\hline & & 2014 & 18 & 168.0 & 322.8 & 18.13 & $<0.0001$ \\
\hline \multirow[t]{2}{*}{ Panicle number } & \multirow[t]{2}{*}{$\mathrm{m}^{-2}$} & 2013 & 18 & 175.0 & 238.5 & 17.87 & 0.017 \\
\hline & & 2014 & 18 & 153.5 & 303.6 & 16.89 & $<0.0001$ \\
\hline \multirow[t]{2}{*}{ Plant height } & \multirow[t]{2}{*}{$\mathrm{cm}$} & 2013 & 18 & 106.2 & 91.4 & 4.82 & 0.036 \\
\hline & & 2014 & 18 & 109.2 & 102.0 & 5.10 & 0.328 \\
\hline \multirow[t]{2}{*}{ 1000-grain weight } & \multirow[t]{2}{*}{$\mathrm{g}$} & 2013 & 18 & 30.1 & 29.7 & 0.42 & 0.527 \\
\hline & & 2014 & 18 & 29.5 & 29.5 & 0.25 & 0.788 \\
\hline \multirow[t]{2}{*}{ Filled grain percentage } & \multirow[t]{2}{*}{$\%$} & 2013 & NA & NA & NA & NA & NA \\
\hline & & 2014 & 18 & 85.4 & 84.04 & 1.10 & 0.380 \\
\hline \multirow[t]{2}{*}{ Weed biomass } & \multirow[t]{2}{*}{$\mathrm{g} \mathrm{m}^{-2}$} & 2013 & 18 & 120.1 & 110.4 & 17.71 & 0.701 \\
\hline & & 2014 & 18 & 85.1 & 49.3 & 7.02 & 0.001 \\
\hline \multirow[t]{2}{*}{ Harvest Index } & \multirow[t]{2}{*}{-} & 2013 & NA & NA & NA & NA & NA \\
\hline & & 2014 & 18 & 0.20 & 0.36 & 0.02 & $<0.0001$ \\
\hline
\end{tabular}

$N A$ data not available

$P$ values $<0.05$ are significantly different

yields in 2013. Farmers might have learned from some of the GAP component technologies in 2013 and consciously or unconsciously implemented these obtained insights into FP plots, in spite of our explicit instructions to maintain exactly the same practices in FP throughout the study. Follow-up surveys on adoption of GAP component technologies are needed to confirm the farmers' knowledge about GAP component technologies and the subsequent inclusion of these practices in their rice production routines.

The farmers' estimated yields were higher than the researcher-measured yields in both seasons. The differences in yields could be due to the use of different methodologies for yield estimation. Farmers' estimated yields in number of bags with unknown moisture content and harvested from the entire plot while researcher-measured yields were from $4-\mathrm{m}^{2}$ areas and the yields were corrected to $14 \%$ moisture content. Researcher-measured yields were therefore more accurate than the farmers' estimated yields and the visiting farmers' anticipated yields. Though there were differences in yield estimations using three different methodologies, the results showed similar yield trends, i.e. yields with GAP were always higher than with FP. The farmers' estimated and visiting farmers anticipated yields were used to understand the farmers' perception on yield with FP and GAP.

\section{Critical assessment of yield advantages achieved with GAP}

The higher yields achieved with the introduction of GAP component technologies in the Kilombero Valley were critically assessed. A strong correlation between the number of panicles and the corresponding grain yields were observed for both FP plots $\left(r^{2}=0.67\right)$ and GAP plots $\left(r^{2}=0.81\right)$ in 2014 (Fig. 3), attesting to the consistency in the observations.

The multiple regression analysis performed to identify the impact of individual GAP component technologies on yield in GAP plots showed that the use of basal inorganic fertiliser and drainage were the main causes for yield differences in the GAP plots among the farmers under irrigated condition (multiple determination coefficient $R^{2}=0.805$ ). The yields were increased by $1.39 \mathrm{t} \mathrm{ha}^{-1}$ in case the basal fertilisers were applied and by $1.68 \mathrm{t} \mathrm{ha}^{-1}$ in case drainage of excess water was done when required (Table 6). The results are directly relating to two of the most important 
Fig. 3 Relationship between panicle number $\left(\mathrm{m}^{-2}\right)$ and grain yield $\left(\mathrm{t} \mathrm{ha}^{-1}\right)$ in all on-farm trials $(n=18)$ in 2014 . The line indicates the linear regression between the two variables
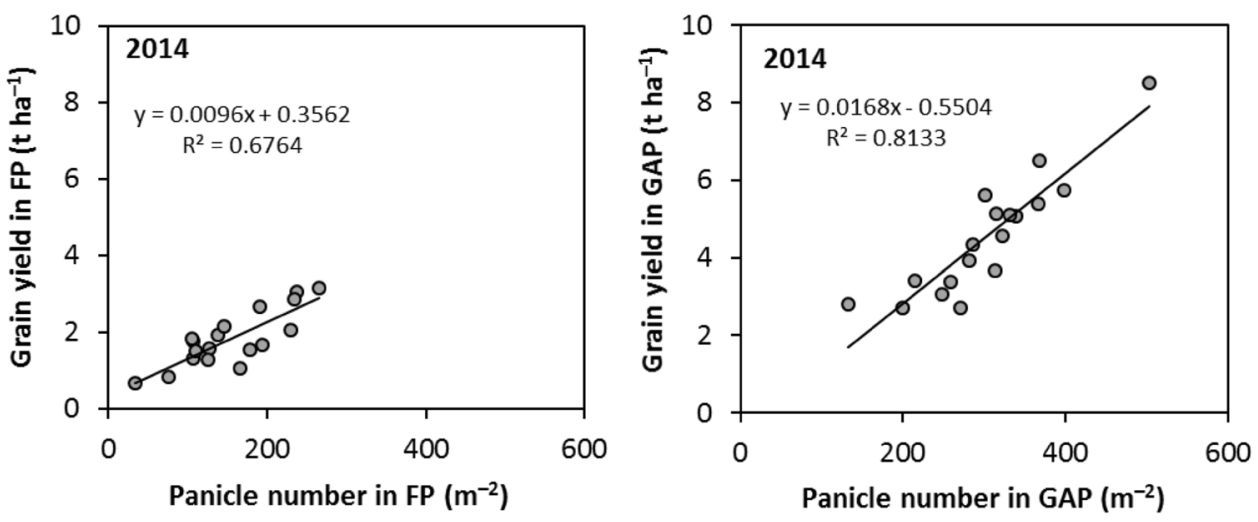

Table 6 Multiple regression analysis showing the GAP component technology that influenced the yield under irrigated and rainfed conditions in both 2013 and 2014

\begin{tabular}{|c|c|c|c|c|}
\hline GAP component technology & Coefficient & $P$ value & $\begin{array}{l}\text { Lower } 95 \% \\
\text { confidence limit }\end{array}$ & $\begin{array}{l}\text { Upper } 95 \% \\
\text { confidence } \\
\text { limit }\end{array}$ \\
\hline
\end{tabular}

(a) Irrigated farmers ( $n=17$; multiple determination coefficient $\left.R^{2}=0.805\right)$

\begin{tabular}{lrrrr} 
Intercept & -1.627 & 0.467 & -6.542 & 3.288 \\
Levelling & 2.063 & 0.057 & -0.082 & 4.209 \\
Thinning/gap filling & 1.740 & 0.098 & -0.406 & 3.885 \\
Inorganic fertiliser (basal application) & 1.392 & 0.046 & 0.035 & 2.749 \\
Herbicide application & -1.875 & 0.349 & -6.218 & 2.469 \\
Rotary weeding (first and second weeding) & -1.334 & 0.260 & -3.872 & 1.204 \\
Hand-weeding (first hand-weeding) & 2.701 & 0.104 & -0.691 & 6.093 \\
Hand-weeding (second hand-weeding) & -1.902 & 0.134 & -4.529 & 0.726 \\
Drainage & 1.682 & 0.021 & 0.325 & 3.038 \\
(b) Rainfed farmers ( $n=19 ;$ multiple determination coefficient $\left.R^{2}=0.286\right)$ & \\
Intercept & 1.339 & 0.695 & -5.933 & 8.611 \\
Bunding & -0.888 & 0.690 & -5.626 & 3.851 \\
Levelling & 0.685 & 0.737 & -3.654 & 5.025 \\
Direct sowing in 20×20 cm spacing & 1.110 & 0.587 & -3.229 & 5.450 \\
Inorganic fertiliser (basal application) & 1.335 & 0.210 & -0.862 & 3.533 \\
Inorganic fertiliser (second top dressing) & 1.453 & 0.456 & -2.658 & 5.564 \\
Herbicide application & 0.824 & 0.456 & -1.507 & 3.155 \\
\hline
\end{tabular}

$P$ values $<0.05$ are significant production factors in rice cultivation, i.e. nutrient and water management. The regression analysis results only partially explained the yield differences in GAP plots. There could be other factors that influenced the yield in GAP plots such as inherent differences in soil fertility, pest and diseases levels and prevailing weather conditions, but these factors were beyond the scope of this analysis. Under rainfed conditions, the regression analysis could not identify any such GAP component technology that impacted the yield significantly in GAP plots (multiple determination coefficient $R^{2}=0.286$ ).

The range of yields reported in the current study overlaps with the range of average rice yields found in previous studies in the region. Average farmers' yields found in the literature range from $3.9 \mathrm{t} \mathrm{ha}^{-1}$ reported in Mauritania (Haefele et al. 2001), $4.2 \mathrm{tha}^{-1}$ — with a maximum of $7.3 \mathrm{tha}^{-1}$-in
Côte d'Ivoire (Becker and Johnson 1999) and $4.8 \mathrm{t} \mathrm{ha}^{-1}$ in Benin (Tanaka et al. 2013), to 5.6 and $6.7 \mathrm{t} \mathrm{ha}^{-1}$ in Senegal (Krupnik et al. (2012) and Haefele et al. (2002b), respectively). The yield range found under farmers' practices in the current study was 0.7 to $4.3 \mathrm{tha}^{-1}$.

The maximum researcher-measured yield following GAP was $8.5 \mathrm{tha}^{-1}$, and this also falls within the range of yields reported from farms across Africa where recommended practices were followed: e.g. $7.8 \mathrm{t} \mathrm{ha}^{-1}$ in Benin (Tanaka et al. 2013) and $7.3 \mathrm{t} \mathrm{ha}^{-1}$ in Côte d'Ivoire (Becker and Johnson 1999), $8.5 \mathrm{t} \mathrm{ha}^{-1}$ in Mauritania (Haefele et al. 2001) and even $9.0 \mathrm{t} \mathrm{ha}^{-1}$ in Senegal (Krupnik et al. 2012). In the current study, the maximum yield $\left(8.5 \mathrm{t} \mathrm{ha}^{-1}\right)$ was achieved by one of the farmers in the 2014 rainfed but waterunlimited trials. This particular farmer was the only farmer 
who followed the complete proposed set of good agricultural practices. For example, she used herbicides followed by mechanical weeding at 20 and 40 DAS, and then conducted follow-up hand-weeding within the crop rows to remove the weeds that were missed by the weeder, as recommended by Rodenburg et al. (2015). Hence, by carefully following up on GAP, high yields can be obtained, but the $8.5 \mathrm{t} \mathrm{ha}^{-1}$ paddy yield is still $15-23 \%$ below the potential (water-unlimited) yield estimated for this area (GYGA 2015; van Ittersum et al. 2016). The remaining yield gap could be due to the relatively low soil fertility of this particular plot. The macro- and micronutrient levels in this field were close to or just above the critical levels of soil nutrients for rice production, as described in Table 3 . The general low potassium and micronutrient levels of the soils in Kilombero were not addressed by the fertiliser application under GAP due to the lack of a reliable market supply of such fertilisers in this area. In line with previous propositions by Tittonell and Giller (2013), the above results would suggest that with better-balanced fertiliser applications, including potassium and micronutrients, rice yields in farmer's fields could be enhanced to further close the yield gap through GAP. This is important information that can be shared with farmers and agro-dealers in the Kilombero Valley in order to improve the supply and application of such types of fertilisers in the future.

\section{Comparison of yield-attributing characteristics}

There were no significant differences in plant population between FP and GAP plots in both years. The number of hills $\mathrm{m}^{-2}$ was 22.6 and 22.5 in FP and 23.1 and 23 in GAP plots in 2013 and 2014, respectively (Table 5). The number of tillers $\mathrm{m}^{-2}$ at harvest was significantly higher in GAP plots than in FP plots in both years. It was 262 and 323 in GAP plots; and 185 and 168 in FP plots in 2013 and 2014, respectively (Table 5). The number of panicles $\mathrm{m}^{-2}$ was significantly higher in GAP plots than in FP plots in most cases (83\%) in 2013 and in all the plots in 2014 (Table 5 and Fig. 4a), which corresponds well to the yield advantages achieved with the GAP plots over FP plots. The plants were taller in FP plots than in GAP plots in both years (Table 5 and Fig. 4b), possibly due to inherent differences in varietal characteristics. The popular variety, SARO5, a short-stature variety (Msomba et al. 2004), was used in all the GAP plots in both years (Table 1). In the FP plots, farmers used local varieties, Kisekese, Kalamata and Super India (Table 1), which are all inherently taller than SARO5 (Luzi-Kihupi et al. 2009). There were no significant differences in the 1000-grain weight and percentage of filled grains between GAP and FP plots (Table 5 and Fig. 4c). The harvest index ranged from 0.06 to 0.37 with a mean of 0.20 for FP plots and from 0.23 to 0.48 with a mean of 0.36 for GAP plots (Table 5 and Fig. 5). The harvest index was higher in 16
GAP plots and almost equal in the remaining two GAP plots over FP plots. The significantly higher harvest index with GAP plots should be due to the use of the aforementioned shorter stature but higher-yielding variety, SARO5, coupled with the implementation of GAP adopted by the farmers.

The weed biomass assessed at harvest was higher in (most of) the FP plots compared to the GAP plots in both seasons, implying more weed pressure with the farmers' weed management practices (Fig. 5). In 2013, the dry weed biomass ranged from 39 to $247 \mathrm{~g} \mathrm{~m}^{-2}$ with a mean of $120 \mathrm{~g} \mathrm{~m}^{-2}$ in FP plots and from 33 to $334 \mathrm{~g} \mathrm{~m}^{-2}$ with a mean of $110 \mathrm{~g} \mathrm{~m}^{-2}$ in GAP plots, while in 2014, it ranged from 39 to $177 \mathrm{~g} \mathrm{~m}^{-2}$ with a mean of $85 \mathrm{~g} \mathrm{~m}^{-2}$ in FP plots and from 19 to $95 \mathrm{~g} \mathrm{~m}^{-2}$ with a mean of $49 \mathrm{~g} \mathrm{~m}^{-2}$ in GAP plots. However, the dry weed biomass was statistically higher in FP plot than GAP plots only in 2014 (Table 5). Overall, the weed pressure was reduced in both FP and GAP plots in 2014 compared to 2013, suggesting that with the experience of the first season, the farmers may have learned to better control weeds in the second season. Indeed, as mentioned before, overall better and more consistent use of mechanical weeders was observed by all the irrigated-rice farmers in 2014 compared to 2013 (Table 4).

\section{Farmers' opinions of GAP component technologies}

According to the participating farmer surveys held after each season, all farmers liked to practice land clearing, tillage, bunding, the use of certified seeds, sowing or planting in lines and maintaining fixed plant spacing within lines, thinning and gap filling, and application of inorganic fertilisers in both seasons (Table 7). They were also convinced that these GAP component technologies are important, whereas most of them found that they can be easily carried out and it is likely that they will continue to use them in the future. However, 22 and 39\% of the farmers in 2013 and 2014, respectively, mentioned that land levelling is difficult to do (Table 7). Furthermore, 10 to $20 \%$ of the farmers mentioned that tilling, bunding, planting or sowing in lines and maintaining fixed plant spacing within lines is difficult to implement.

The farmer surveys indicated that none of the farmers applied organic manures in any of the seasons. It was observed that they do not like to apply organic manures or that they felt that it was not important, and they do not intend to use them in the future. Reasons for not using organic fertilisers could be the lack of knowledge, labour constraints and the poor short-term benefits, as observed with farmers in northern Ghana by Becx et al. (2012). The total absence of the use of organic fertilisers by the farmers surveyed in the current study also explains the very poor soil fertility status of their soils (Table 3). Non-application of animal manures 
(a) Number of panicles
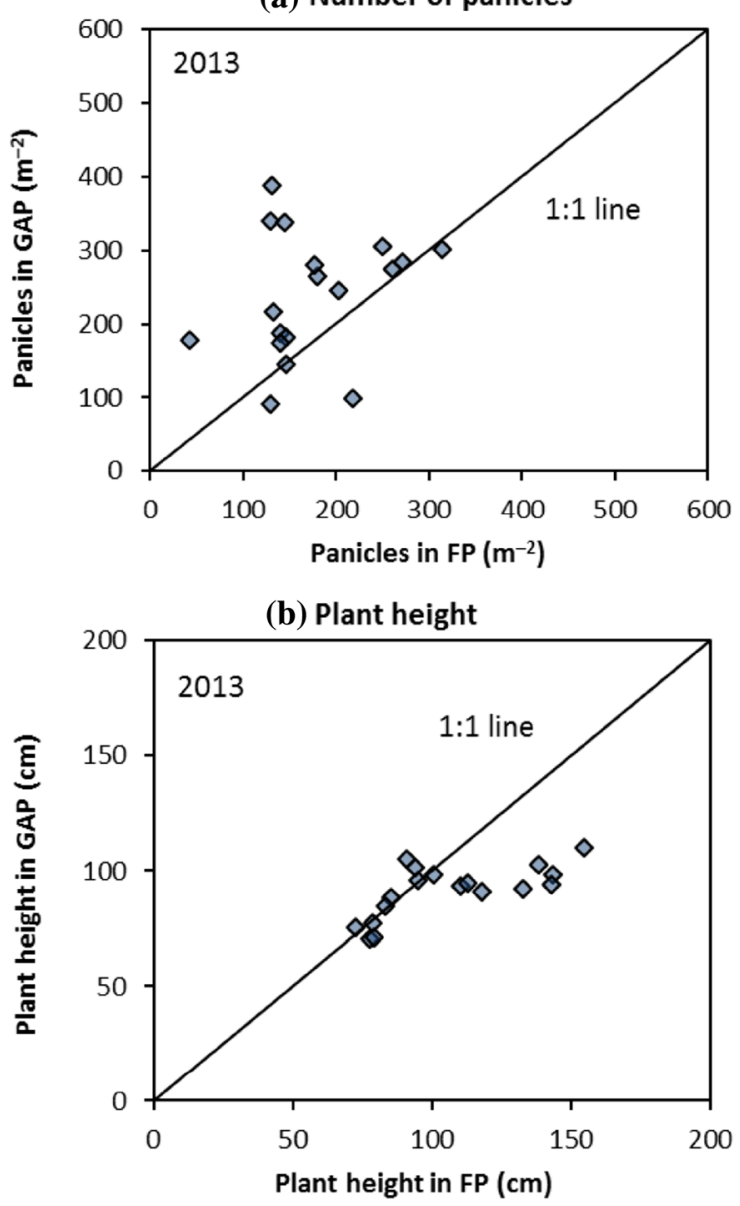

(c) 1000-grain weight

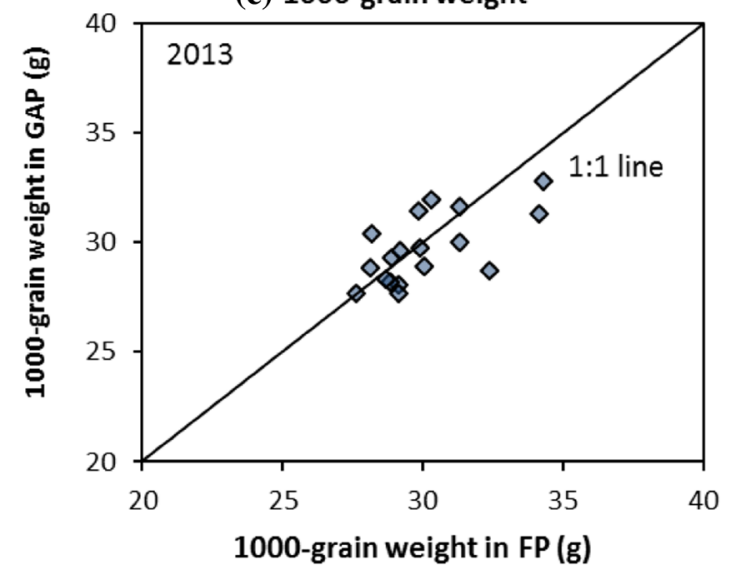

(a) Number of panicles

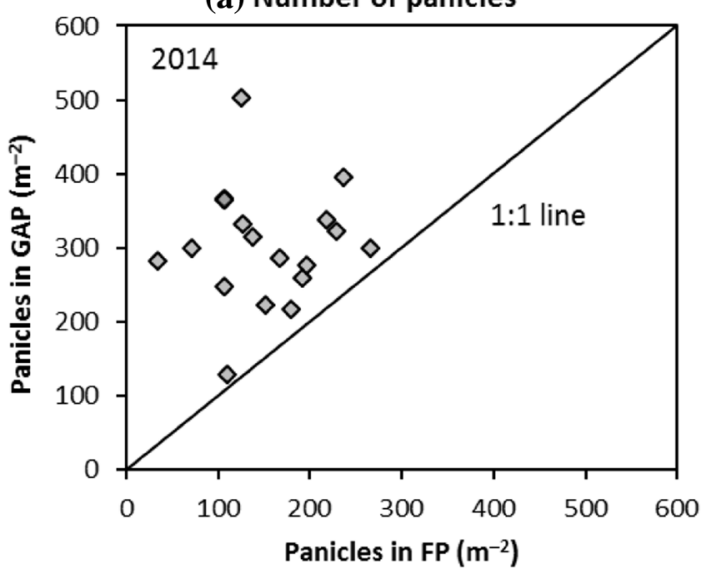

(b) Plant height

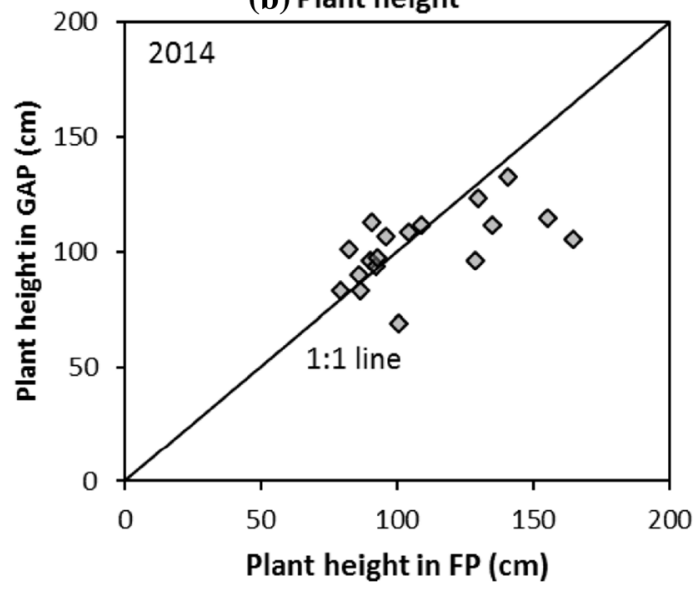

(c) 1000-grain weight

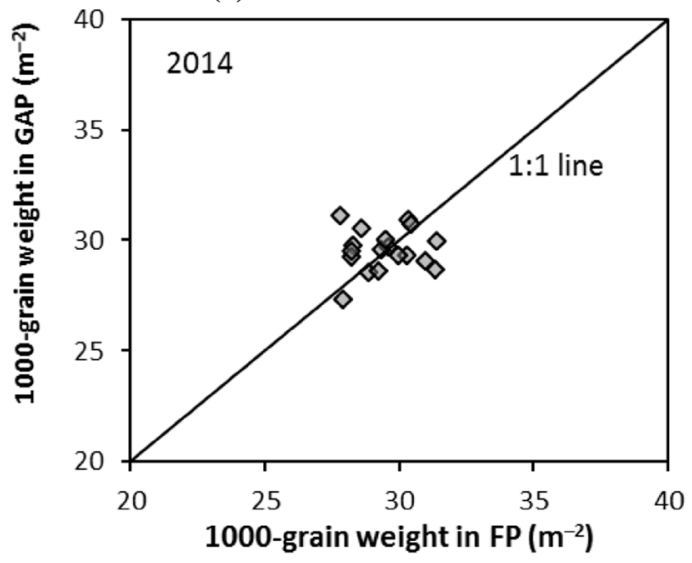

Fig. 4 Rice yield attributes of GAP (good agricultural practices) over FP (farmers' practices) in the on-farm trials ( $n=18$ ) in Kilombero in 2013 and 2014

with the monoculture of rice could be the cause of the very low levels of micronutrients such as $\mathrm{B}, \mathrm{S}$ and $\mathrm{Mg}$, as shown by Castellanos-Navarrete et al. (2015), Rufino et al. (2007), and Schulz et al. (2011). Since organic fertilisers could offer an affordable and good alternative to the more expensive mineral fertilisers (Marenya et al. 2012; Epule et al. 2015), future development and extension efforts to raise awareness and demonstrate the options and effects of the use of organic soil amendments would be a valuable investment in this area. 

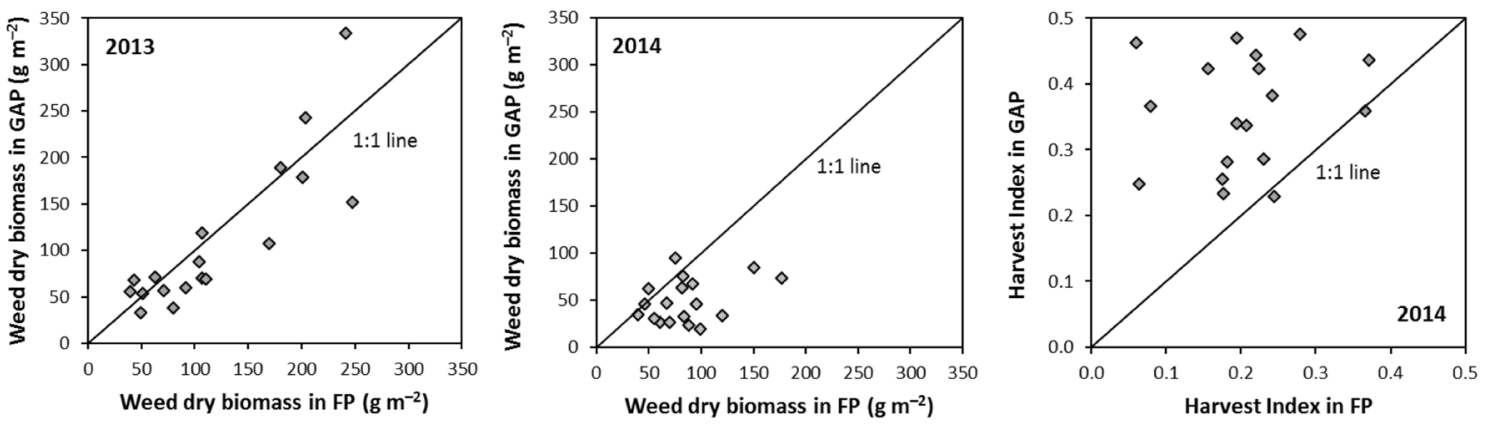

Fig. 5 Weed dry biomass $\left(\mathrm{g} \mathrm{m}^{-2}\right)$ and Harvest Index in GAP over FP in the on-farm trials $(n=18)$ in Kilombero in 2013 and 2014

In the case of weed control, all farmers found that the application of herbicides is easy to do and most of them (78\% in 2013 and $83 \%$ in 2014) preferred this mode of weed control (Table 7). However, $87-89 \%$ of the irrigated-rice farmers and 78-80\% of the rainfed-rice farmers did not actually use herbicides (Table 7), possibly because of the costs involved-a common adoption constraint for herbicides-in addition to limited market access (Rodenburg and Johnson 2009). Most of the farmers (72\% in 2013 and $89 \%$ in 2014) liked the mechanical weeders, and a similar share of farmers found them useful and important. However, the remaining share of farmers reported that it was difficult to operate them, and $67-78 \%$ of the farmers in 2013 and $50 \%$ of the farmers in 2014 were not sure whether they would use them in the future (Table 7). Interestingly, the number of farmers that indicated that they would use the mechanical weeders in the future increased from 22 to $33 \%$ for the first and second mechanical weeding, respectively, in 2013, to $50 \%$ for both weeding interventions in 2014. This implies that the use of the mechanical weeder becomes easier and/or more efficient with experience. Similar findings have been reported with the use of mechanical weeders in Asia where farmer adoption increased with experience (Senthilkumar et al. 2008). These observations support the necessity to conduct more research on designing and adapting locally acceptable, user-friendly mechanical weeders to improve adoption. With the introduction and increasing experience with the mechanical weeders, the preference for the laborious practice of hand-weeding operations decreased from 28 and $44 \%$ for the first and second hand-weeding, respectively, in 2013 , to $83 \%$ for both hand-weeding interventions in 2014. Hand-weeding is a common practice in SSA in any rice-growing environment, and consumes a major share of the farmers' time spent on crop management (Akobundu 1987; Lodin-Bergman et al. 2012; Ogwuike et al. 2014). The result of this study supports the general assumption that subsistence farmers need adapted labour-saving technologies.

The GAP component technologies that are specific to irrigated rice, such as preflooding, puddling, follow-up irrigation and drainage before harvest, were appreciated by all the irrigated-rice farmers. They also felt that these practices are important, easy to implement and that they will continue using them in the future.

\section{Potential impact of adopting GAP in rice production in Tanzania}

The results of the on-farm trials demonstrated the yield gains that can be achieved with the adoption of GAP component technologies in Tanzania. An average yield gain of $1 \mathrm{t} \mathrm{ha}^{-1}$ in 2013 and $2.7 \mathrm{t} \mathrm{ha}^{-1}$ in 2014 was achieved with the implementation of GAP by the farmers in the Kilombero Valley (Fig. 2b). The follow-up farmer surveys showed the adoption potential of the GAP component technologies by the farmers.

This case study of the Kilombero Valley showed the potential of exposing farmers to GAP on boosting the rice yields in Tanzania. Farmer training and the farmers' own experiences with GAP can be used as a tool in large-scale rice-farming extension efforts to transform rice production in Tanzania. This will trigger a positive change in the participating farmer's crop management and their livelihood. However, an enabling environment should be created for rice farmers to increase their rice production through the adoption of GAP component technologies. This means improving farmers' awareness and providing access to certified seeds of improved varieties, balanced mineral fertilisers, smallscale agricultural implements and machinery, and creating a viable rice value chain that would ensure reliable supply and demand markets (Demont 2013). 


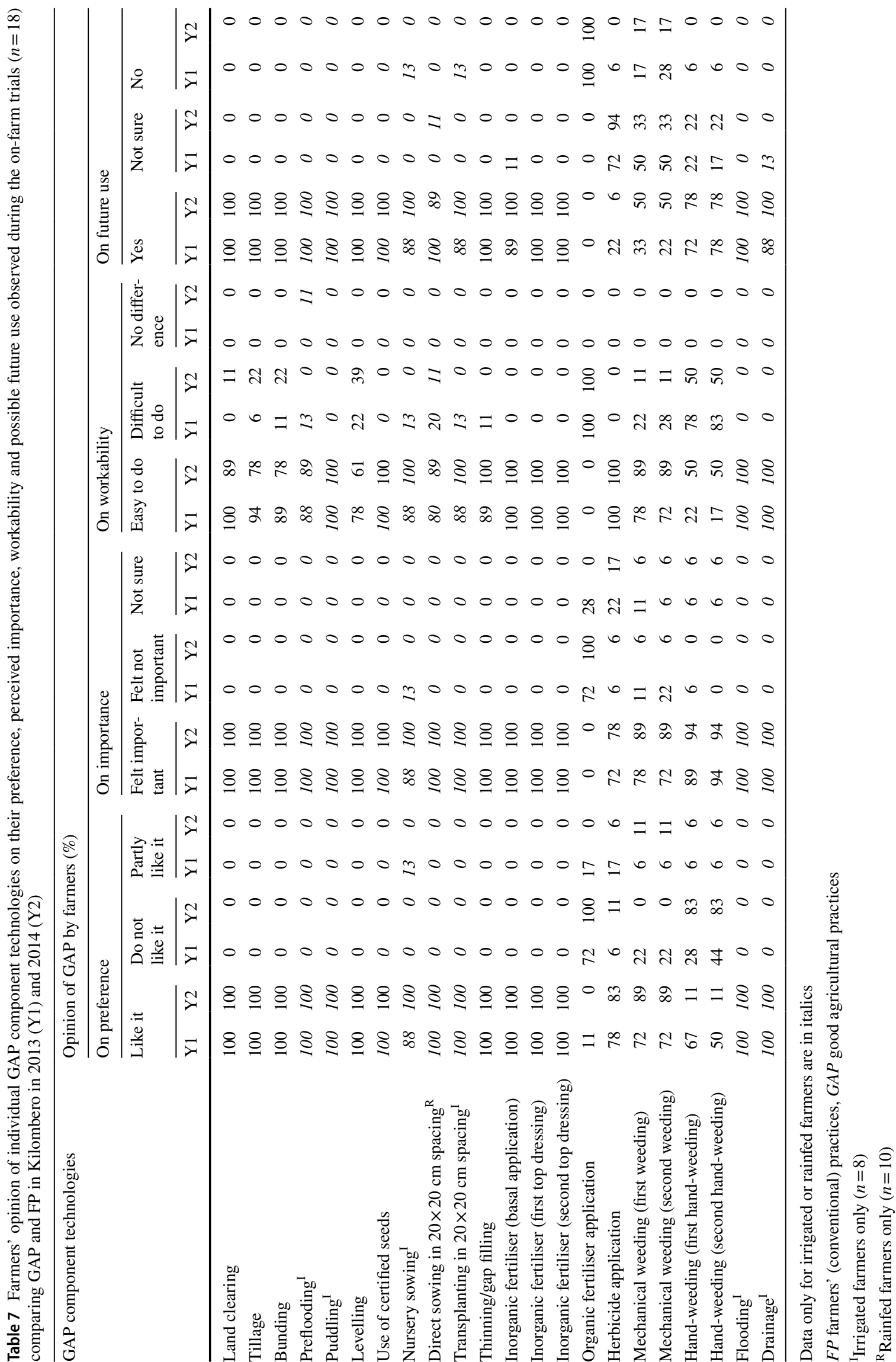




\section{Conclusions}

Large yield gains can be achieved by smallholder rice farmers in sub-Saharan Africa through the implementation of good agricultural practices (GAP). The yield gains using GAP was achieved through increased panicle number, higher harvest index, and reduced weed pressure. While smallholder rice farmers are often resource poor, they are usually able to implement most of the component technologies that constitute such GAP and are capable of improving the implementation of these practices over time by familiarising themselves with the techniques. Exposure to GAP, in the way done in this study, may encourage farmers to use at least some of its components in the future. While farmers may find certain component technologies of GAP difficult to implement (i.e. land levelling, planting or sowing in line, and maintaining fixed plant spacing within lines), they also generally see the importance of these technologies and appreciate the yield improvements obtained with them. This provides a valuable outlook for future development efforts in the rice sector in sub-Saharan Africa. While follow-up training of farmers and impact assessment studies are required to ascertain GAP adoption and to provide proof of the effectiveness of the methods followed in this study, the case of the Kilombero Valley shows that rice yields can be substantially improved by relatively simple adjustments of current farmer practices. Moreover, this case study indicates that the adoption of GAP by smallholder rice farmers can be triggered by stimulating experimentation with such practices on their own farms. Larger-scale exposure of farmers to these practices, e.g. by the institutionalisation of nationwide training programmes on GAP technologies, or the production and dissemination of farmer-to-farmer instruction videos, is required to capitalise on the lessons learned in this study in order to boost lowland rice yields in Tanzania as well as in other rice-producing countries in SSA.

\begin{abstract}
Acknowledgements We thank the African Development Bank (AfDB) and the United States Agency for International Development (USAID) for funding this research through the SARD-SC and Africa RISING project, respectively. We thank the enumerators Stella Mghase, Ditric Mwingira, Wenseslaus Mishiko, David Lihepanyama, Emmanuel Makoninde and Dominic Ilaila, from the Kilombero Agricultural Training and Research Institute (KATRIN), for their assistance in conducting the trials and data collection. We thank Ibnou Dieng, Africa Rice Center for his assistance with the statistical analysis. This is an output of the CGIAR Research Programme, GRiSP, the Global Rice Science Partnership. The CGIAR Big Data Platform in Agriculture project supported the open access of this publication.
\end{abstract}

Open Access This article is distributed under the terms of the Creative Commons Attribution 4.0 International License (http://creativeco mmons.org/licenses/by/4.0/), which permits unrestricted use, distribution, and reproduction in any medium, provided you give appropriate credit to the original author(s) and the source, provide a link to the Creative Commons license, and indicate if changes were made.

\section{References}

Addinsoft (2007) Data and statistical analysis with MS Excel, NY Akobundu IO (1987) Weed science in the tropics. Principles and practices. Wiley, Chichester

Balasubramanian V, Sie M, Hijmans RJ, Otsuka K (2007) Increasing rice production in Sub-Saharan Africa: challenges and opportunities. Adv Agron 94:55-132. https://doi.org/10.1016/S0065 -2113(06)94002-4

Becker M, Asch F (2005) Iron toxicity in rice-conditions and management concepts. J Plant Nutr Soil Sci 168:558-573. https:// doi.org/10.1002/jpln.200520504

Becker M, Johnson DE (1999) Rice yield and productivity gaps in irrigated systems of the forest zone of Côte d'Ivoire. Field Crop Res 60:201-208

Becker M, Johnson DE (2001) Improved water control and crop management effects on lowland rice productivity in West Africa. Nutr Cycl Agroecosyst 59:119-127

Becker M, Johnson DE, Wopereis MCS, Sow A (2003) Rice yield gaps in irrigated systems along an agro-ecological gradient in West Africa. J Plant Nutr Soil Sci 166:61-67

Becx G, Mol G, Eenhoorn J et al (2012) Perceptions on reducing constraints for smallholder entrepreneurship in Africa: the case of soil fertility in Northern Ghana. Curr Opin Environ Sustain 4:489-496. https://doi.org/10.1016/j.cosust.2012.10.012

Boonchuay P, Cakmak I, Rerkasem B, Prom-U-Thai C (2013) Effect of different foliar zinc application at different growth stages on seed zinc concentration and its impact on seedling vigor in rice. Soil Sci Plant Nutr 59:180-188

Castellanos-Navarrete A, Tittonell P, Rufino MC, Giller KE (2015) Feeding, crop residue and manure management for integrated soil fertility management - a case study from Kenya. Agric Syst $134: 24-35$

Ceesay M (2010) An opportunity for increasing factor productivity for rice cultivation in The Gambia through SRI. Paddy Water Environ 9:129-135. https://doi.org/10.1007/s10333-010-0235-1

Demont M (2013) Reversing urban bias in African rice markets: a review of 19 National Rice Development Strategies. Glob Food Secur 2:172-181. https://doi.org/10.1016/j.gfs.2013.07.001

Diagne A, Amovin-Assagba E, Futakuchi K, Wopereis MCS (2013) Estimation of cultivated area, number of farming households and yield for major rice-growing environments in Africa. In: Wopereis MC, Johnson DE, Ahmadi N et al (eds) Realizing Africa's rice promise. CABI, Wallingford, pp 35-45

Epule ET, Bryant CR, Akkari C, Daouda O (2015) Can organic fertilizers set the pace for a greener arable agricultural revolution in Africa? Analysis, synthesis and way forward. Land Use Policy 47:179-187. https://doi.org/10.1016/j.landusepol.2015.01.033

Fageria N, Carvalho G, Santos A et al (2011) Chemistry of lowland rice soils and nutrient availability. Commun Soil Sci Plant Anal 42:1913-1933. https://doi.org/10.1080/00103624.2011.591467

Fairhurst TH, Witt C, Buresh RJ, Dobermann A (2007) Rice-a practical guide to nutrient management. International Rice Research Institute, Los Baños

Felister M, Speelman S, Van Huylenbroeck G et al (2011) Ratification of the Ramsar convention and sustainable wetlands management: situation analysis of the Kilombero Valley wetlands in Tanzania. J Agric Ext Rural Dev 3:153-164

Foster A, Rosenzweig M (1995) Learning by doing and learning from others: human capital and technical change in agriculture. J Polit Econ 103:1176-1209

Gongotchame S, Dieng I, Ahouanton K et al (2014) Participatory evaluation of mechanical weeders in lowland rice production systems in Benin. Crop Prot 61:32-37. https://doi.org/10.1016/j. cropro.2014.03.009 
GYGA (2015) Global yield gap atlas [Home page]. http://www.yield gap.org/gygamaps/app/index.html. Accessed 18 Feb 2016

Haefele SM, Johnson DE, Diallo S et al (2000) Improved soil fertility and weed management is profitable for irrigated rice farmers in Sahelian West Africa. Field Crop Res 66:101-113

Haefele S, Wopereis MC, Donovan C, Maubuisson J (2001) Improving the productivity and profitability of irrigated rice production in Mauritania. Eur J Agron 14:181-196. https://doi.org/10.1016/ S1161-0301(00)00094-0

Haefele S, Wopereis MC, Wiechmann H (2002a) Long-term fertility experiments for irrigated rice in the West African Sahel: agronomic results. Fields Crop Res 78:119-131. https://doi. org/10.1016/S0378-4290(02)00117-X

Haefele SM, Wopereis MCS, Donovan C (2002b) Farmers' perceptions, practices and performance in a sahelian irrigated rice scheme. Exp Agric 38:197-210. https://doi.org/10.1017/S0014 47970200025X

Haefele S, Nelson A, Hijmans R (2014) Soil quality and constraints in global rice production. Geoderma 235-236:250-259. https://doi. org/10.1016/j.geoderma.2014.07.019

Heiniger R, Havlin J, Crouse D et al (2002) Seeing is believing: the role of field days and tours in precision agriculture education. Precis Agric 3:309-318

Jin Z, Minyan W, Lianghuan W et al (2008) Impacts of combination of foliar iron and boron application on iron biofortification and nutritional quality of rice grain. J Plant Nutr 31:1599-1611. https ://doi.org/10.1080/01904160802244803

Kilimo Trust (2014) Expanding rice markets in the East African community: an opportunity for actors in the rice value chain. Competitive Africa Rice Initiative (CARI), Dar es Salaam, Tanzania, 64 pp

Kondylis F, Mueller V, Zhu SJ (2014) Seeing is believing? Evidence from an extension network experiment. World Bank Group, Development Research Group, Washington, p 57

Krupnik TJ, Shennan C, Settle WH et al (2012) Improving irrigated rice production in the Senegal River Valley through experiential learning and innovation. Agric Syst 109:101-112. https://doi. org/10.1016/j.agsy.2012.01.008

Laker M (2005) Appropriate plant nutrient management for sustainable agriculture in Southern Africa. Commun Soil Sci Plant Anal 36:89-106

Lodin-Bergman J, Paulson S, Mugenyi MS (2012) New seeds, gender norms and labor dynamics in Hoima District, Uganda. J East African Stud 6:405-422

Luh Y (1995) Are farmers learning by doing? Experience in Taiwan. Rev Agric Econ 17:213-227. https://doi.org/10.2307/1349734

Luzi-Kihupi A, Zakayo JA, Tusekelege H et al (2009) Mutation breeding for rice improvement in Tanzania. Food and Agricultural Organization (FAO), Rome, pp 385-387

Marenya P, Nkonya E, Xiong W et al (2012) Which policy would work better for improved soil fertility management in sub-Saharan Africa, fertilizer subsidies or carbon credits? Agric Syst 110:162172. https://doi.org/10.1016/j.agsy.2012.04.004

Mowo J., Floor J, Kaihura FBS, Magogo JP (1993) Review of fertilizer recommendations for Tanzania. Soil fertility report No. F6. ARIMlingano, National soil Services, Ministry of Agriculture, Tanga, Tanzania, pp 25-29

Msomba SW, Kibanda JM, Penza H et al (2004) TXD306-a highyielding and medium-maturing aromatic rice for the rainfed lowland and irrigated ecosystems in Tanzania. Int Rice Res Notes 29:30-31

Nguyen N, Ferrero A (2006) Meeting the challenges of global rice production. Paddy Water Environ 4:1-9. https://doi.org/10.1007/ s10333-005-0031-5

Nhamo N, Rodenburg J, Zenna N et al (2014) Narrowing the rice yield gap in East and Southern Africa: using and adapting existing technologies. Agric Syst 131:45-55
Nwite JC, Igwe CA, Wakatsuki T (2008) Evaluation of sawah rice management system in an inland valley in southeastern Nigeria. I: soil chemical properties and rice yield. Paddy Water Environ 6:299-307. https://doi.org/10.1007/s10333-008-0123-0

Ogwuike P, Rodenburg J, Diagne A et al (2014) Weed management in upland rice in sub-Saharan Africa: impact on labor and crop productivity. Food Secur 6:327-337. https://doi.org/10.1007/s1257 1-014-0351-7

Olaleye AO, Ogunkunle AO, Singh BN et al (2009) Ratios of nutrients in lowland rice grown on two iron toxic soils in Nigeria. J Plant Nutr 32:1336-1352. https://doi.org/10.1080/01904160903006036

Pansu M, Gautheyrou J (2007) Handbook of soil analysis: mineralogical, organic and inorganic methods. Springer, Berlin, p 993

Poussin J-C, Diallo Y, Legoupil J-C (2006) Improved collective decision-making in action for irrigated rice farmers in the Senegal River Valley. Agric Syst 89:299-323. https://doi.org/10.1016/j. agsy.2005.09.006

Rashid A, Ryan J (2004) Micronutrient constraints to crop production in soils with Mediterranean-type characteristics: a review. J Plant Nutr 27:959-975. https://doi.org/10.1081/PLN-120037530

Rodenburg J, Johnson D (2009) Weed management in rice-based cropping systems in Africa. Adv Agron 103:149-218. https://doi. org/10.1016/S0065-2113(09)03004-1

Rodenburg J, Meinke H, Johnson DE (2011) Challenges for weed management in African rice systems in a changing climate. J Agric Sci 149:427-435. https://doi.org/10.1017/S0021859611000207

Rodenburg J, Zwart SJ, Kiepe P et al (2014) Sustainable rice production in African inland valleys: seizing regional potentials through local approaches. Agric Syst 123:1-11. https://doi.org/10.1016/j. agsy.2013.09.004

Rodenburg J, Saito K, Irakiza R et al (2015) Labor-saving weed technologies for lowland rice farmers in sub-Saharan Africa. Weed Technol 29:751-757. https://doi.org/10.1614/WT-D-15-00016.1

Rufino MC, Tittonell P, van Wijk MT et al (2007) Manure as a key resource within smallholder farming systems: analysing farmscale nutrient cycling efficiencies with the NUANCES framework. Livest Sci 112:273-287. https://doi.org/10.1016/j.livsc i.2007.09.011

Schulz E, Breulmann M, Boettger T et al (2011) Effect of organic matter input on functional pools of soil organic carbon in a long-term double rice crop experiment in China. Eur J Soil Sci 62:134-143. https://doi.org/10.1111/j.1365-2389.2010.01330.x

Senthilkumar K, Bindraban PS, Thiyagarajan TM et al (2008) Modified rice cultivation in Tamil Nadu, India: yield gains and farmers' (lack of) acceptance. Agric Syst 98:82-94

Senthilkumar K, Lubbers M, de Ridder N et al (2011) Policies to support economic and environmental goals at farm and regional scales: outcomes for rice farmers in Southern India depend on their resource endowment. Agric Syst 104:82-93

Senthilkumar K, Bindraban PS, de Ridder N et al (2012) Impact of policies designed to enhance efficiency of water and nutrients on farm households varying in resource endowments in south India. NJAS Wageningen J Life Sci. https://doi.org/10.1016/j.njas.2012.01.002

Tanaka A, Saito K, Azoma K, Kobayashi K (2013) Factors affecting variation in farm yields of irrigated lowland rice in southerncentral Benin. Eur J Agron 44:46-53. https://doi.org/10.1016/j. eja.2012.08.002

Tittonell P, Giller KE (2013) When yield gaps are poverty traps: the paradigm of ecological intensification in African smallholder agriculture. Field Crop Res 143:76-90. https://doi.org/10.1016/j. fcr.2012.10.007

Touré A, Becker M, Johnson DE et al (2009) Response of lowland rice to agronomic management under different hydrological regimes in an inland valley of Ivory Coast. Field Crop Res 114:304-310. https://doi.org/10.1016/j.fcr.2009.08.015 
van Ittersum MK, van Bussel LGJ, Wolf J et al (2016) Can sub-Saharan Africa feed itself? Proc Natl Acad Sci USA 113:14964-14969. https://doi.org/10.1073/pnas.1610359113

van Ranst E, Verloo M, Demeyer A, Pauwels JM (1999) Manual for the soil chemistry and fertility laboratory: analytical methods for soils and plants equipment, and management of consumables, $243 \mathrm{pp}$ van Oort PAJ, Saito K, Tanaka A et al (2015) Assessment of rice selfsufficiency in 2025 in eight African countries. Glob Food Secur 5:39-49. https://doi.org/10.1016/j.gfs.2015.01.002
Wopereis MCS, Defoer T, Idinoba P, et al (2007) Participatory learning and action research (PLAR) for integrated rice management (IRM) in Inland Valleys of Sub-Saharan Africa: Technical Manual. WARDA Training Series. WARDA, Bouaké, Côte d'Ivoire, and IFDC, Muscle Shoals, AL, USA, $136 \mathrm{pp}$

Zimdahl R (2007) Fundamentals of weed science. Academic Press, London, p 666 